\title{
Complementing firewood with alternative energy sources in Rio Pardo Watershed, Brazil
}

\section{Luana Dessbesell ${ }^{1}$ Jorge Antonio de Farias ${ }^{2}$ Fábio Roesch ${ }^{3}$}

\author{
${ }^{1}$ Faculty of Natural Resources Management, Lakehead University, Thunder Bay, Ontario, Canada, P7B 5E1. E-mail: 1dessbes@lakeheadu.ca. \\ ${ }^{*}$ Corresponding author. \\ ${ }^{2}$ Departamento de Ciências Florestais, Universidade Federal de Santa Maria (UFSM), Santa Maria, RS, Brasil. \\ ${ }^{3}$ Japan Tobacco International, Santa Cruz do Sul, RS, Brasil.
}

ABSTRACT: Wood is the primary energy source for grains and Tobacco drying in the Rio Pardo Watershed (RPW). The amount of firewood produced in the RPW is not enough to supply the demand. Recently, an automatized supply system was introduced in the region enabling the use of sawdust and pellets. In this context, this study aims to compare firewood, sawdust and pellets as energy sources for Tobacco curing in air-forced curing systems. Energetic density was used to estimate the biomass consumption in Tobacco curing. The consumption of biomass is lower for pellet, followed by firewood and sawdust. Pellets and sawdust could complement firewood in the region; however, research is necessary to ascertain the economic feasibility.

Key words: tobacco, pellet, sawdust, energetic density.

Fontes alternativas para energia em complementação a

lenha na Bacia Hidrográfica do Rio Pardo, Brasil

RESUMO: A madeira é fonte fundamental de energia na secagem da produção agrícola na Bacia Hidrográfica do Rio Pardo. A lenha disponível na região não é suficiente para suprir a demanda. Recentemente, um sistema de alimentação automatizado possibilitou o uso de materiais como serragem e pellets na secagem da produção. Portanto, nesse estudo comparou-se a energia consumida na cura do tabaco para lenha, serragem e pellets em unidades de cura de ar-forçado. A densidade energética foi utilizada para estimar o consumo de biomassa das fontes de energia utilizadas na cura do tabaco. Constatou-se que o consumo de biomassa é menor para o pellet, seguido da lenha e por último a serragem. Serragem e pellets podem ser alternativas energéticas na região. No entanto, estudos são necessários para afirmar se há viabilidade econômica.

Palavras-chave: tabaco, pellet, serragem, densidade energética.

Environmental and financial issues have driven the research on forest residues for energy production. Farmers in the Rio Pardo Watershed (RPW), for example, are in need of energy alternatives to firewood shortage. The region is well known for the main industrial Tobacco plants in Brazil. Furthermore, firewood is the source of heat used in Tobacco curing, accounting for around $8 \%$ of the Tobacco's production cost (AFUBRA, 2013). The lack of forest plantations for firewood lead to higher transportation cost because farmers have to purchase firewood from outside the region resulting in economic resources evasion.

The RPW also owns a number of small size sawmills that are producing residues, e.g. sawdust, daily. According to the Rio Grande do Sul State Environmental Department, 107 sawmills were registered with the department in 2013 (RIO GRANDE DO SUL 2013). Introduction of a feed system that facilitates and controls the fuel feed to the furnace enabled the use of sawdust and pellets for Tobacco curing and grains drying. Farmers aiming to low their production cost have been testing the system; however, there is no data to evaluate the biomass consumption to provide farmers with reliable options to deal with the firewood shortage. sSo, this study seeks to compare firewood, sawdust, and pellets regarding energy consumption in Tobacco curing in air-forced curing units in the RPW.

The biomass (firewood and sawdust) consumption per kilogram of Tobacco cured was measured during the 2013/2014 crop season in two farms located in the municipality of Candelária, RPW, RS, Brazil. The farms have the same air-forced curing unit (Figure 1B). In this system, the Tobacco leaves are arranged in metal clips designed to hold the leaves inside the curing unit. The clips with Tobacco were weighed before and after the curing process. 
For the sawdust/pellets system, the automatized feed system connected to the furnace feeds the biomass. An electronic control system monitors and regulates the quantity of biomass to maintain the temperature according to the drying program chosen. The biomass is automatically directed by a screw conveyor located at the bottom of the feed funnel. A container with known dimensions and weight was used to measure the sawdust, where the number, weight and volume of each full container was recorded.

To estimate firewood utilization, all wood logs used were weighted and measured to calculate the volume trough the Smalian method. In this system, the furnace is feed by men-power; furthermore, in both systems, a sonorous signal alerts when the unit needs to be loaded.

The sawdust volume available in the RPW was retrieved from literature and government data. The following procedure was employed to estimate the amount of sawdust available: total number of sawmills multiplied by average wood volume sawn by sawmill multiplied by a sawdust yield factor of 0.15 (EKONO, 1980). The author reported that each tonne $(\mathrm{t})$ of hardwood processed in small size sawmills generates $0.5 \mathrm{t}$ of sawn wood, $0.35 \mathrm{t}$ of material that can be used for plywood panels, and $0.15 t$ of losses that could be used for energy production. The Energetic Density (ED) in Gcal $\left(\mathrm{m}^{3}\right)^{-1}$ was used to compare the biomass sources. The ED uses the available heating value (AHV, $\mathrm{kcal} \mathrm{kg}^{-1}$ ) and the density (D) to estimate the available energy of the material. The AHV is measured by the low heating value (LHV) and moisture $(\mathrm{U}, \%)$ of the material. The DE and AHV are calculated as follows (MOREIRA et al., 2012):

$$
E D=\frac{D \times A H V}{10^{6}} \quad A H V=L H V \times \frac{(100-U)}{100}-6 \times U
$$

Where: D: basic density $\left(\mathrm{kg}\left(\mathrm{m}^{3}\right)^{-1}\right)$ for firewood, and bulk density for pellets and sawdust; divided by $10^{6}$ to convert to Gcal; HHV: higher heating value; LHV: HHV-324 ( $\mathrm{kcal} \mathrm{kg}^{-1}$ ).

The sawdust used at the farm was chosen to characterize the region; therefore, sawdust samples were collected at the sawmill that supply sawdust to the farm. The sample was sent to the CIENTEC laboratory in Porto Alegre, RS, Brazil. The analysis respected standard methodologies: moisture - NBR 14660; HHV ASTM D 5865, ash - ASTM D 7582; sulfur - EN 15289; and, carbon, hydrogen and nitrogen - ASTM D 5373.

About $84.6 \%$ of the wood processed in the sawmills in the region come from Eucalyptus sp. plantations, mostly of Eucalyptus grandis. Therefore, it is assumed that the sample represents the sawdust available in the region. And, the ED of Eucalyptus sp. pellets was obtained from GARCIA et al. (2013). Finally, the basic density of firewood was obtained from MOREIRA et al. (2012). The firewood consumption for Tobacco curing has decreased in the last years. From around $12 \mathrm{~kg}$ offirewood perkg of Tobacco cured (KILEWE et al., 1989) in traditional curing units (masonry, Figure 1A) to around $4.5 \mathrm{~kg} \mathrm{~kg}^{-1}$ of Tobacco (MUSONI et al., 2013). Improvements in the curing units and structural adaptations in the piping that directs heat in from the furnace resulted in a decrease in the firewood consumption.

The adoption of air-forced units (Figure 1B) increased in the last 10 years, in those units, the firewood utilization measured was $3.96 \mathrm{~kg} \mathrm{~kg}^{-1}$ of Tobacco. And the consumption of sawdust was $3.61 \mathrm{~kg} \mathrm{~kg}^{-1}$ of Tobacco. Air-forced units are more efficient in heat production and distribution than the traditional ones. Besides the firewood system requires heavy physical effort to feed the furnace, and direct contact of the operator with smoke and soot.

The sample collected presented a moisture content on a dried basis of $32.62 \%$. Biomass should have a moisture content lower than $25 \%$ for an efficient combustion because high moisture decreases the energy available, and reduces the furnace temperature resulting in more soot in the structure (PEREIRA et al., 2000). Percentage of fixed carbon reported in the sawdust was 51.56. Fuels with higher fixed carbon contents are preferable because they burn slowly. Also, carbon and hydrogen are the elements that most contribute to the heating value of fuels. The ash content detected for sawdust was $0.66 \%$; it usually ranges from $0.5 \%$ up to $5 \%$, depending on the species, amount of bark, soil and sand in the sample (PEREIRA et al., 2000).

The ED $\left(\mathrm{GJ}\left(\mathrm{m}^{3}\right)^{-1}\right)$ calculated was as follows, firewood 6.28, pellets 11.57 and sawdust 2.00. The firewood presented an ED 3.15 times higher than the sawdust. And the ED of pellets was 5.78 times higher than the sawdust; based on this difference it can be estimated a pellets consumption for Tobacco drying of $2.08 \mathrm{~m}^{3} \mathrm{t}^{-1}$ of Tobacco. It could be inferred that the densification process results in $82.66 \%$ reduction in biomass consumption compared to sawdust. The pellets presented an ED 1.84 times higher than the firewood. Comparing pellets consumption per $\mathrm{t}$ of Tobacco $\left(2.08 \mathrm{~m}^{3} \mathrm{t}^{-1}\right)$ with the firewood $\left(5.0 \mathrm{~m}^{3} \mathrm{t}^{-1}\right)$ notices a reduction of $45.60 \%$. This comparison demonstrates the potential of pellets in Tobacco curing.

It is estimated that $69.87 \mathrm{t} \mathrm{d}^{-1}$ of sawdust are available for energy production in the RPW. This amount could produce 11.733, 12t $\mathrm{yr}^{-1}$ of pellets. The RPW contains 22,840.00 farms growing Tobacco. Each farm produces on average $4.46 \mathrm{tr}^{-1}$ of Tobacco. And, around $2 / 3$ of the firewood consumed in the region is purchased and that $61.4 \%$ of the amount comes from outside of the RPW (AFUBRA, 2013). Based on the amount of firewood purchased from outside of the RPW, pellets could replace $16.19 \%$ of this amount. Finally, if the sawdust is utilized 
A
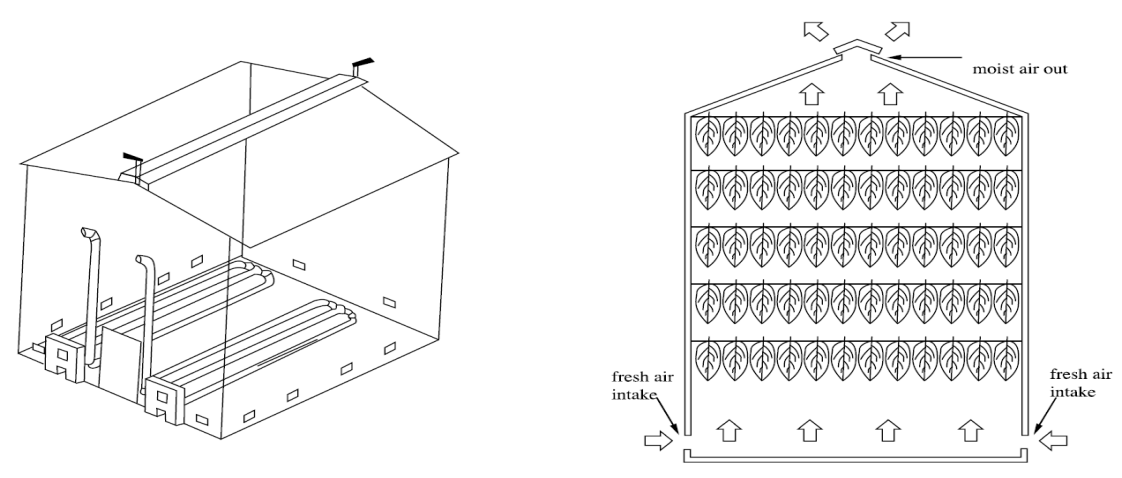

B
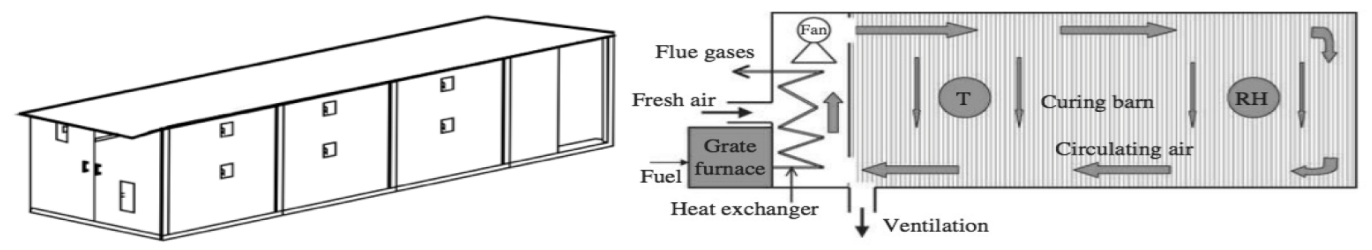

Figure 1 - A: traditional curing unit (masonry); B: air-forced curing unity. Source: C: adapted from TIPPAYAWONG et al. (2004), and D: XIAO et al. (2015).

without transformation, it could supply only $3.53 \%$ of the firewood purchased from outside of the region.

This study showed the need for alternative energy sources to supply rural communities' demand, such as the RPW, to assist local farmers to deal with wood shortage and maintain their main source of income. Sawdust available in the RPW could be an alternative source of energy in its current form or transformed in pellets. Since biomass consumption in Tobacco curing is lower for pellets followed by firewood and sawdust. However, more studies are necessary to confirm the environmental, technical and economic feasibility of pellets usage, also considering the costs of the biomass feed system.

\section{ACKNOWLEDGEMENTS}

Japan Tobacco International (JTI); Programa de Pósgraduação em Engenharia Florestal (PRPGPF - UFSM); Coordenação de Aperfeiçoamento de Pessoal de Nível Superior (CAPES).

\section{VERBAL INFORMATION}

AFUBRA (ASSOCIAÇÃO DOS FUMICULTORES DO BRASIL). Accessed: May 10, 2013.

\section{REFERENCES}

EKONO, O. Power and heat plants. Local: Helsinki. Food and Agriculture Organization of the United Nation, 1980. Available from: <https://goo.gl/67i3CB>. Accessed: July 15, 2016.
GARCIA, D.P. et al. Caracterização energética de pellets de madeira. Revista da Madeira. n.135, p.14-18, 2013. Available from: <https://goo.gl/6CA0rf>. Accessed: Jan. 28, 2015.

KILEWE, A.M. et al. Agroforestry development in Kenya: second Kenya national seminar on agroforestry, 1989. Available from: <https:/goo.gl/g2cwXw>. Accessed: July 15, 2016.

MOREIRA, J.M.M.A.P. et al. Impacto do teor de umidade e da espécie florestal no custo da energia útil obtida a partir da queima da lenha. Local: Colombo, Embrapa Florestas, 2012. 5p. (Tech. Inform.).

MUSONI, S. et al. Redesign of commonly used Tobacco curing barns in Zimbabwe for increased energy efficiency. International Journal of Engineering Science and Technology, v.5, 609p, 2013. Available from: <https://goo.gl/jmR5Wi>. Accessed: July $15,2016$.

PEREIRA, J.C.D. et al. Características da madeira de algumas espécies de eucalipto plantadas no Brasil. Local: Colombo, Embrapa Florestas, 2000. 113p. (Tech. Inform.).

RIO GRANDE DO SUL. Secretaria Estadual de Meio Ambiente. Relatório. Santa Cruz do Sul, 2013. 300p.

TIPPAYAWONG, N. et al. Energy and emission based performance of an experimental Tobacco bulk-curing barn. Chiang Mai University Journal, v.3, n.1, p.43-51, 2004. Available from: $<$ https://goo.gl/arosUt>. Accessed: July 15, 2016.

XIAO, X. et al. Industrial experiments of biomass briquettes as fuels for bulk curing barns. International Journal of Green Energy, v.12, p.1061-1065, 2015. Available from: <https://goo.gl/2bK8Pd $>$. Accessed: July 15, 2016. doi: 10.1080/15435075.2014.891119. 